AperTO - Archivio Istituzionale Open Access dell'Università di Torino

\title{
Current tectonic activity and differential uplift along the Cottian Alps/Po Plain boundary (NW Italy) as derived by PS-InSAR data
}

\section{This is the author's manuscript}

Original Citation:

Availability:

This version is available http://hdl.handle.net/2318/133381

since 2015-12-23T10:48:55Z

Published version:

DOI:10.1016/j.jog.2013.02.004

Terms of use:

Open Access

Anyone can freely access the full text of works made available as "Open Access". Works made available under a Creative Commons license can be used according to the terms and conditions of said license. Use of all other works requires consent of the right holder (author or publisher) if not exempted from copyright protection by the applicable law. 


\section{(3) \\ UNIVERSITÀ DEGLI STUDI DI TORINO}

This is an author version of the contribution published on:

Questa è la versione dell'autore dell'opera:

Journal of Geodynamics 66, 2013, 65-78, 10.1016/j.jog.2013.02.004]

The definitive version is available at:

La versione definitiva è disponibile alla URL:

www.elsevier.com/locate/jog 


\title{
Current tectonic activity and differential uplift along the Cottian Alps/Po Plain boundary (NW Italy) as derived by PS-InSAR data
}

\author{
Perrone G. ${ }^{(1)}$, Morelli M. ${ }^{(2)}$, Piana F. ${ }^{(3)}$, Fioraso G. ${ }^{(3)}$, Nicolò G. ${ }^{(2)}$, Mallen L. ${ }^{(2)}$, Cadoppi P. ${ }^{(1,4)}$, \\ Balestro G. ${ }^{(1,4)}$, Tallone S. ${ }^{(3)}$
}

1 - Dipartimento di Scienze della Terra- Università di Torino

2 - ARPA Piemonte

3 - CNR-Istituto di Geoscienze e Georisorse- Unità di Torino

4 - Research Centre on Natural Risks in Mountain and Hilly Environments (NatRisk)

Keywords: PS-InSAR interferometry, current tectonics, Western Alps, Northern Apennines, seismotectonics

\begin{abstract}
Iso-Kinematic maps have been derived from spatial statistics (Hot Spot and geostatistical analysis) of Permanent Scatterers Interferometric Synthetic Aperture Radar (PS-InSAR) data, and compared with geological, geomorphological, seismological and GPS data in order to analyse the current tectonics and the crustal mobility, at the boundary between the Cottian Alps and the Western Po Plain. This area corresponds to the subsurface junction between the Western Alpine chain and the Northern Apennines.

PS data show that the Western Alps are currently uplifting with respect to the adjoining Western Po Plain, as confirmed by the GPS data. The Iso-Kinematic Boundary between these two sectors partly coincides with a regional N-S fault system developed along the inner seismogenic border of the Cottian Alps. Focal mechanisms indicate transpressive movements along this Iso-Kinematic Boundary, which separates two domains characterized by different fault geometry and kinematics, namely: $a$ ) the Cottian Alps, where N-S transtensive/normal faults have developed, and $b$ ) the subsurface Western Po Plain, where NW-SE transpressive/reverse faults are dominant.
\end{abstract}


This articulated tectonic setting results from the complex strain partitioning of the oblique convergence between the European and Adria plates, which is still ongoing, as indicated by seismotectonic and geodetic data.

\section{Introduction}

The westernmost Po Plain, south of Turin, masks at surface the deep indentation of the Alpine and Apennine orogenic belts. The Alps-Apennines junction zone, which is subjected to moderate differential uplift, as observed by GPS data (Devoti et al., 2011), is affected by low magnitude instrumental seismicity $\left(\mathrm{M}_{\mathrm{L}}<5\right)$ despite the fact that historically, earthquakes that have struck this area have reached up to a moderate magnitude (seismic event of the April $2^{\text {nd }}, 1808, M s=5,5$; Boschi et al., 2000).

Some studies (Delacou et al., 2004, 2008; Perrone et al., 2010, 2011b; Sue et al., 2007; Sue and Tricart, 2003), have served to shed new light on the seismotectonics of the Western Alpine chain, but further investigations are required to fully understand its relationship with the current tectonics of the adjoining Western Po Plain, where information regarding the active tectonics is scarce.

Due to its geological complexity, low magnitude seismicity and lack of evidence of Quaternary deformations, the more recent seismotectonic interpretations for this area had to be based on the results of multidisciplinary studies (Perrone et al., 2010, 2011b) in which different datasets (geological, structural and seismological) were merged and compared.

Recently Morelli et al. (2011) used PS-InSAR interferometry data to constrain the analysis at a regional scale of the tectonic mobility of low deformation settings, such as the study area. Continuous PS-velocity surface maps (Iso-Kinematic Maps: IKM), obtained from spatial statistics of interferometry data (Hot Spot and geostatistical analysis), were used for direct comparison of PSInSAR data with the geological maps, through the individuation of PS kinematically-homogeneous domains, regardless of absolute PS-velocity values, and characterization of the boundaries between them (Iso-Kinematic Boundaries). When Iso-Kinematic Boundaries correspond with known geological features, they can be used to constrain seismotectonic or regional kinematic models. In the case that IKB do not correspond with known geological features, it can be suggested that: $i$ ) IKB could have originated as a result of non-geological factors or ii) new geological models could be envisaged to fit with the PS-InSAR data.

In this study, PS-InSAR data have been statistically analysed to generate IKM of the inner Cottian Alps (between the Stura di Lanzo and Po valleys) and the Western Po Plain (Fig. 1). These new 
IKM have been compared with the available geological, structural, geomorphological, seismological and GPS data to study the relationship between differential uplift, crustal mobility and the current tectonic activity of this sector. This study contributes to improving the knowledge of the current tectonic activity in the Western Po Plain and provides some new constraints for the recently outlined seismotectonic model (Perrone et al., 2010, 2011b) of one of the most populated areas of Northern Italy.

Figure 1 here

\section{Geological framework}

The study area includes the inner sector of the Cottian Alps (Italian Western Alps) and the subsurface western termination of the Northern Apennine chain which is masked at surface by the fluvial deposits of the Western Po Plain (Fig. 2). In the following section, the major brittle structural features and the post-Oligocene tectonic evolution of these two domains will be briefly reviewed. Subsequently, the Quaternary evolution of the Western Po Plain will be analysed.

\subsection{The inner Cottian Alps}

The Cottian Alps (CA) consists of a nappe stack constituted by oceanic and continental units belonging to the Penninic and Austroalpine Domain (Fig. 1, 2). These units were tectonically superposed during the Alpine orogenic cycle and underwent high pressure/low temperature metamorphic conditions during subduction, followed by greenschists re-equilibration during continental collision (Polino et al., 1990 with references). Available apatite and zircon fission track data indicate that, since the Oligocene, these tectonic units were exhumed at shallow crustal levels $(<10 \mathrm{~km})$ and displaced by a complex fault network (Balestrieri et al., 2004; Bernet et al., 2001; Cadoppi et al., 2002; Malusà et al., 2005; Perrone et al., 2011a; Tricart et al., 2007).

The major semi-brittle to brittle faults affecting this part of the Alpine chain, from the inner to the external sector (from East to West), correspond to $(i)$ the Col del Lis-Trana Deformation Zone (LTZ) and (ii) the Colle delle Finestre Deformation Zone (CFZ). Between these regional discontinuities other minor faults are also present.

The Col del Lis-Trana Deformation Zone (LTZ in Fig. 1, 2) corresponds to an N-S, sub-vertical structure that runs from the Lower Stura di Lanzo to the Lower Sangone valleys, reactivating the contact between different tectonic units. Seismic (cross-section 2-2' in Fig. 3) and geological data 
suggest that the Col del Lis-Trana Deformation Zone should extend southwards along the inner Alpine border, beneath the Plio-Quaternary deposits of the Po Plain, reaching about $50 \mathrm{~km}$ in total length. This structure seems to overlap with the western border of the high magnetic anomaly of the Ivrea body, suggesting that it could be rooted at depth into the boundary between geological bodies that are characterized by a strongly different density. The Col del Lis-Trana Deformation Zone firstly acted as a dextral transpressive brittle-ductile shear zone and later as a brittle normal fault at least up until Quaternary time (Perrone et al., 2010; 2011a). West of the LTZ, some E-W (Sangone and Chisone Fault; Fig. 2) and N-S (Pinasca-Gran Dubbione Fault system; Fig. 2) faults are present, interpreted as its second order synthetical and antithetical structures, respectively (Collo and Giardino, 1997; Perrone et al., 2011b).

The Colle delle Finestre Deformation Zone corresponds to a steeply dipping N-S discontinuity inferred from the Lower Susa to the Middle Chisone valley (Carraro et al., 2002). The occurrence of a clearly evident N-S morphostructural lineament system, which may be followed along the western limit of the Dora-Maira Unit (Cadoppi et al., 2007), suggests that the Colle delle Finestre Deformation Zone should be part of a regional fault system still not well characterized by the available geological data. Structural data indicate that the kinematics of this structure changes from right-lateral to normal (Tallone et al., 2002). Fission tracks data suggest that this change could have occurred in the Late Oligocene-Early Miocene (see Perrone et al., 2011a for further details)

Geometry and kinematics of the aforementioned faults indicate that the post-Oligocene tectonic evolution of the Cottian Alps could be the result of a bulk dextral transtensive regime at the regional scale, which induced both right-lateral and normal/transtensive movements along the major faults that bound the chain along its inner border like the Col del Lis-Trana Deformation Zone and the Colle delle Finestre Deformation Zone (see Perrone et al., 2011a and references therein). This transtensive regime is likely to be induced, at the crustal scale, by the coexistence of two driving forces that have been active since the late Oligocene, namely: the anticlockwise rotation of the Adria plate and the body forces acting inside the chain (Delacou et al., 2004; Perrone et al., 2010, 2011a, 2011b; Sue and Tricart, 2003).

\section{Figure 2 here}

\subsection{The Western Po Plain area and the subsurface "Alps-Apennines" junction zone}

The Quaternary deposits of the Western Po Plain mask at surface the tectonic junction area between metamorphic units of the Western Alps, sedimentary successions of the Southern Alps resting on 
the Adria crust, detached non-metamorphic Ligurian units and Oligocene-to-Pliocene succession of the inner Alpine syn-orogenic basins. The syn-orogenic basins are subdivided here into four units: the north-Padane Oligocene-Miocene basin (partially corresponding to the so-called Gonfolite basin), the south-Padane Late Eocene-to-Late Miocene basin ("Tertiary Piemonte Basin Auctorum"), the Savigliano basin and the Alessandria basin (Fig. 1).

Since the latest Oligocene, the tectonic scenario of this area was dominated by the convergence of north-verging Ligurian units and south-verging Southern Alps units over the Adria foreland. The Gonfolite basin was progressively involved in compressional tectonics, while transtensive and transpressive tectonics led to a complex sedimentary evolution of the Tertiary Piemonte Basin, subdivided into partially independent sub-basins (Clari et al., 1995; Gelati and Gnaccolini, 1988; Mosca et al., 2009; Polino et al., 2002; Rossi et al., 2009). Since the late Miocene, the Southern Alps thrusts have been progressively deactivated and the $\mathrm{N}$-verging Apennines tectonics has prevailed in the collisional system. The Tertiary Piemonte Basin has evolved as a wide thrust top basin (Bello and Fantoni, 2002; Cassano et al., 1986; Festa et al., 2009; Mosca et al., 2009; Piana and Polino, 1995; Piana, 2000). N-verging thrusts (Padanian Thrust Front; PTF in Figs. 1, 2 and 3) cut the successions of the Tertiary Piemonte Basin at their base, causing the formation of the NESW trending Torino Hill anticline, the southward tilting of Monferrato and the displacement of the older South-Alpine thrusts (Fig. 3). The occurrence of the south-Alpine crust at shallow levels under the Torino Hill tectonic unit may have represented a major obstacle to the progressive westward propagation of the north-verging thrust systems. As a consequence, the regional N-S shortening imposed by the convergence of the South Alpine and Apennine systems has been accommodated closer to the southwest by the N-verging buried Saluzzo-Sommariva del Bosco Thrust Fault (SSB in Fig. 1, 2 and 3), and by a continuous, tectonically-driven uplift of the southern parts of the Tertiary Piemonte Basin. Since this moment the Savigliano and the Alessandria subsiding basins have developed at the rear of the Padanian Thrust Front (Bigi et al., 1990; Mosca et al., 2009). The more recent activity of this fault in the Pleistocene seems to be related both to its westward propagation and to the progressive SW-ward tilting of the Torino Hill anticline, which is interpreted to have caused the diversion of the Po River (Carraro et al., 1995). No clear evidence of Holocene tectonic activity has been demonstrated for the Padanian Thrust Front in the study area.

\section{Figure 3 here}

\subsection{Quaternary succession of the inner Cottian Alps - Torino Hill transect}


In the Cottian Alps - Torino Hill transect, the Western Alps and the deformed successions of the TPB are subjected to differential Quaternary evolution.

The Cottian Alps has been affected by strong exogenic modelling related to the Middle-Late Pleistocene multistage glaciations, and to inter- and post-glacial fluvial erosion. Glacial modelling has mostly affected the Susa valley, where a wide morainic amphitheatre has developed at the valley mouth, causing, after the glacial retreat, the development in the Late Pleistocene of a glaciolacustrine basin. By contrast, in the Stura di Lanzo, Sangone, Chisone and Pellice valleys, glaciers did not ever reach the Western Po Plain. The development of Pleistocene intra-mountain lacustrine basins in the lower Pellice and Chisone valleys may be, therefore, related to the activity of the N-S faults bordering the inner part of the Alpine chain (Perrone et al., 2010, 2011b and references therein).

Consequent over-deepening of valley bottoms and over-steepening of slopes induce diffuse postglacial rock mass disequilibrium, with the development of huge and diffuse landslides and deepseated gravitational slope deformations (Fig. 2).

In the Torino Hill, widespread fluvial terraces that are distributed along the NW and SE slopes up to 200-250 m above the Po Plain may be related to the Pleistocenic tectonic evolution of the NWverging Padanian Thrust Front. The high relief of this area favours the development of diffuse instability phenomena such us shallow landslides, at the expense of the Torino Hill and Monferrato succession. Furthermore, widespread and deep-seated karst phenomena involve the Messinian gypsum bodies distributed along the south-western slope of the Torino Hill (Fioraso et al., 2004; Vigna et al., 2010).

The Westernmost Po Plain is made up of a series of coalescent fluvial and fluvio-glacial megafans, Middle-to-Late Pleistocene in age, and fed by the Stura di Lanzo, Dora Riparia, Sangone and Pellice rivers. North of Moncalieri, the fluvial succession is widely terraced, while to the South it is instead predominantly characterized by depositional and river impoundment processes that were active until the Holocene (Fig. 2). Peat bogs and plant remains (dated between 30,660 \pm 1290 and $5,855 \pm 75$ yr BP; Tropeano and Cerchio, 1984) intercalated within the late Upper Pleistocene to Holocene fluvial succession, south of Moncalieri, could be related to the growing of the Torino Hill anticline.

\section{Seismotectonic framework}

The study area is affected by low-magnitude seismicity $\left(\mathrm{M}_{\mathrm{L}}<5\right.$; Eva et al., 1997; Sue et al., 1999, 2007; Perrone et al., 2011a, 2011b). Instrumental and historical seismicity are mostly concentrated 
along a longitudinal band, known as the Piedmont seismic arc, roughly sub-parallel to the inner border of the Alpine chain (Fig. 4). The hypocentres are relatively shallow inside the Alpine chain, usually being confined within the first $15-20 \mathrm{~km}$ of crust. By contrast, in the Western Po Plain, the seismicity is distributed within the entire crust, reaching a depth of 40-50 km (Eva et al., 1997; Eva and Solarino, 1998).

Focal mechanisms (Bethoux et al., 2007; Delacou et al., 2004; Eva et al., 1997; Eva and Solarino, 1998) indicate a contrasting stress regime in the inner Cottian Alps. Transcurrent and extensional mechanisms, with steep $\mathrm{P}$ axes and sub-horizontal roughly $\mathrm{E}-\mathrm{W}$ trending $\mathrm{T}$ axes, are widespread inside the Cottian Alps. Compressive and transpressive solutions, with sub-horizontal roughly E-W trending P axes, are instead concentrated in the westernmost Po Plain.

Seismotectonic studies (Perrone et al., 2010, 2011a) recently showed that the seismic activity of this area could be partly related to the current activity of the N-S regional faults (Col del Lis-Trana Deformation Zone) affecting the inner border of the Cottian Alps, as seismological and structural data show consistent geometry (map view and cross-section) and kinematics (Fig. 4). This suggests that the dextral transtensive regime in the Western Alps is still ongoing (Delacou et al., 2004, 2008; Perrone et al., 2010, 2011b; Sue et al., 2007; Sue and Tricart, 2003).

By contrast, in the westernmost Po Plain, focal mechanisms indicate that contraction is still ongoing, although the relationship between faults and seismicity are poorly understood. Béthoux et al. (2007) hypothesized, on the basis of seismic and magnetic interpretations, which the physical limit between these different stress regimes is represented by the southern prolongation in the study area of the Insubric Fault.

More recent seismotectonic interpretations (Delacou et al., 2004, 2008; Perrone et al., 2010, 2011b) have shown that these data fit with a model that postulates transtensive deformation inside the Alpine chain, due to the coexistence of gravitational body forces and transcurrent movements, and transpressive deformation both in the more external (Jura chain) and internal (Western Po Plain) sectors. This implies that the convergence, associated with the anticlockwise rotation between the Adriatic and European plates, is still ongoing. The magnitude of seismic events and the GPS data indicate low deformation rates (Calais et al., 2002; Delacou et al. 2004, 2008; Nocquet and Calais, 2003). Geodetic data show that the rotation pole of the Adria plate is located between the Western Po Plain and the French Alps (Anderson and Jackson, 1987; Calais et al., 2002; Ward, 1994).

\section{Figure 4 here}

\section{Deformation and uplift rate by GPS data}


GPS data indicate a general uplift that follows the topographic ridge of the Alpine chain, whereas a general subsidence trend is observed in the Po Plain. For the study area, GPS data indicate an uplift rate of usually less than 1-2 mm/yr in the Western Alps, and a subsidence rate of less than $2 \mathrm{~mm} / \mathrm{yr}$ in the Western Po Plain (Devoti et al., 2011).

On an enlarged scale, the uplifting trend of the Alps seems to be currently controlled by the combination of different factors, for example, the isostatic rebound and climatic change (Champagnac et al., 2007; Delacou et al., 2004). According to these studies, in fact, a significant part $(50 \%)$ of the present-day uplift of the Western Alps can be ascribed to the isostatic response of the Alpine lithosphere to enhanced erosion rates, which resulted from deglaciation and melting of the ice cap caused by the climatic change occurred in the late upper Pleistocene).

In addition to the tectonic component, the subsidence of the Po Plain seems to be driven by the consolidation of thick Quaternary sediments (Carminati et al., 2003).

Geodetic data also indicate a shortening in the westernmost Po Plain/Western Alps boundary and an extension in the chain, albeit with low deformation rates (Calais et al., 2002; Devoti et al., 2011). GPS measurements also indicate a NW-SE extension, at a rate of $1.4 \pm 0.4 \mathrm{~mm} / \mathrm{yr}$, inside the Western Alps and an E-W to NW-SE convergence, at a rate of $1.0 \pm 0.5 \mathrm{~mm} / \mathrm{yr}$, in the Western Po Plain (Calais et al., 2002), in agreement with the seismotectonic data (cfr. par. 3).

\section{Present-day ground deformation by PS-InSAR data: methodology and statistical analysis}

\subsection{The PS-InSAR technique}

Satellite interferometry data is based on phase comparison of SAR images acquired at different times and perspective views (Curlander and McDonough, 1991). Permanent Scatterers Interferometric Synthetic Aperture Radar (PS-InSAR, Ferretti et al., 2001) is one of the latest applications of SAR time series data analysis. Permanent Scatterers are radar image points on the ground (edifices and other anthropic objects affected by corner effects, and naturally-exposed polished surfaces) which show stable interferometric phase behaviour for wide look-angle variations over time, i.e. a high long-term phase coherence and a strong and stable backscatter level. As PS do not change their spectral responses for different acquisitions, the phase dispersion due to temporal and geometrical decorrelation phenomena, which negatively affect Radar interferometry, are strongly reduced using PS as measurement points. Therefore, PS can be used as natural 
elements to estimate the progressive sub-vertical motion (about $<23^{\circ}$ from the vertical axis and the satellite line of sight - LOS) of the ground surface.

PS velocity values are relative to a stable reference point, chosen within the PS dataset. The precision of the PS velocities, which can range from 0.1 to $1 \mathrm{~mm} /$ year depending on their coherence (Ferretti et al., 2007), decreases with distance from the reference point. The coherence is a normalized index of the local signal-to-noise ratio of the interferometric phase (Hansen, 2001; Colesanti et al., 2003). The standard approach utilized in this study assumes the deformation is linear in time (i.e. a constant velocity).

Given their abundance, PS points can be considered as a very dense geodetic network. Their spatial density is variable, since high densities are associated with urban environments, while low densities are observed in uninhabited, agricultural landscapes, vegetated areas and on areas affected by foreshortening, layover and shadowing effects on the relative SAR images.

In this study, 163 satellite images ERS-1 and ERS-2 SAR descending scenes (track 22 and frame 2709 available from ESA) were analysed. These scenes that were taken from May 1992 to January 2001, enabled the detection of more than 400,000 PS in the analysed area, with an average density of $160 \mathrm{PS} / \mathrm{km}^{2}$.

\subsection{Statistical analysis}

Histogram frequency diagrams were used to describe the main statistical features of PS data set distribution of the two geological sectors (corresponding to the areas covered by IKM1 and IKM2, see below) analysed in this study (Fig. 5). Both sectors showed unimodal slightly asymmetrical distributions, with negative skew more prominent in the IKM2 (Fig. 5 and Table 1). Moreover, both sectors show high values of negative outliers, reaching down to $-27 \mathrm{~mm} / \mathrm{yr}$ and $-20 \mathrm{~mm} / \mathrm{yr}$, and high positive outliers of $+17 \mathrm{~mm} / \mathrm{yr}$ and of $+6 \mathrm{~mm} / \mathrm{yr}$ for IKM1 and IKM2, respectively.

Although the high negative velocity values are probably due to the occurrence of gravitational phenomena (landslides and Deep Seated Gravitational Slope Deformations) or rapid compaction of sediments, the positive values seem to be too high with respect to the average known velocity of the tectonic crustal mobility of this area. However, it is stressed that this work does not focus on analysis of absolute PS-velocity values, but only on comparing PS velocities of different IsoKinematic areas. The meaning of absolute PS-velocity values is still uncertain, not only because of the small time span of the PS-data set, but mainly because PS values are relative to a fixed reference point. In fact the red and blue colours shown in Figures 6 and 7 represent areas with relative movement towards and away from satellites. 


\subsection{Geostatistical and spatial cluster analysis}

Due to the large amount of PS data and their high spatial variability (Fig. 5), the spatial distribution of the PS data set has been analysed by geostatistical and spatial cluster techniques (Hot Spot analysis). In order to obtain higher quality of PS data, only the PS with a coherence threshold greater or equal than 0.8 have been statistically analysed (coherence ranging from 0 to 1 , see Ferretti et al., 2000).

Hot Spot statistic (Getis and Ord, 1992) is calculated as follows:

$$
G i *(d)=\frac{\sum w i j(d) x j}{\sum_{j} x j}
$$

where wij(d) is a binary spatial weight matrix with ones for all links defined as being within distance $d$ of focal point $i$; all other links are zero. The numerator is the sum of all $x j$ within $d$; the denominator is the sum of all $\mathrm{xj}$ in the whole spatial domain. $\mathrm{Gi}^{*}(\mathrm{~d})$ is a measure of concentration or lack of concentration of the sum of values associated with variable $\mathrm{X}$ in a given region.

By taking the statistic minus its expectation, and dividing by the square root of its variance, a new measure is obtained (Ord and Getis, 1995):

$$
Z(G i *)=\frac{G i *(d)-E(G i *(d))}{\sqrt{\operatorname{Var}(G i *(d))}}
$$

$\mathrm{Z}\left(\mathrm{Gi}^{*}\right)$ indicates how many standard deviations $\mathrm{Gi}^{*}(\mathrm{~d})$ differs from its expected value $\mathrm{E}\left(\mathrm{Gi}^{*}(\mathrm{~d})\right)$, introducing a measure of significance in the former statistic (equation (1)). The higher the absolute value of $\mathrm{Z}\left(\mathrm{Gi}^{*}\right)$ is, the more confident we are that the $\mathrm{Gi}^{*}(\mathrm{~d})$ value is anomalous, along with the sum of the xj values within distance d. Concentration of positive (hot spot) and negative (cold spot) significant values of $\mathrm{Z}\left(\mathrm{Gi}^{*}\right)$ identify clusters of anomalous PS-velocity values. $\mathrm{Z}\left(\mathrm{Gi}^{*}\right)$ was calculated for three different distances d: $10 \mathrm{~km}, 5 \mathrm{~km}$, and $2.5 \mathrm{~km}$. For this study, the $\mathrm{d}=2.5 \mathrm{~km}$ resulted as being the most appropriate for the generation of the hot spot maps (Fig. 6, 7) considering the geological and geomorphological features, the extent of the investigative area, and the statistical distribution of the data. 


\section{Figure 5 here}

\subsection{Generation of Iso-Kinematic Maps}

Hot spot analysis is a statistic technique that enables the accurate identification of Iso-Kinematic domains and their boundaries, without allowing the evaluation of the velocity gradient across them. To estimate these features, the ordinary kriging interpolation method of Hot Spot results was utilized (Morelli et al., 2011). These techniques rely on the spatial correlation of Hot Spot data, as inferred by variography analysis, to determine the weighting values.

These techniques have been used to define continuous velocity surface maps, (here referred to as Iso-Kinematic Maps- IKM; see Morelli et al., 2011 for a more detailed explanation regarding the methodological approach) where Iso-Kinematic domains and Iso-Kinematic Boundaries are compared to geological data (Fig. 6, 7). Iso-Kinematic domains represent land sectors characterized by homogeneous kinematic behaviour and the Iso-Kinematic Boundaries are statistical limits that bound them. Boundary geometry can be very straight or curvilinear, very narrow (less than one kilometre) with high velocity gradients or very wide with gentle gradients. Different geological meanings can be inferred for the Iso-Kinematic Boundaries, depending on the geometry and velocity gradients observed across them.

Two partially overlapping Iso-Kinematic Maps were generated (IKM1 and IKM2) to analyze the differential uplift and crustal mobility between the inner Cottian Alps and the Western Po Plain (Fig. 6 and 7). The most striking feature of both the IKM1 and IKM2 is the strong differential uplift between the inner border of the Alpine chain, where positive to highly positive PS velocities are strongly concentrated, and the Western Po Plain, where generally low positive to negative values are observed. The Iso-Kinematic Boundary between these two Iso-Kinematic domains is characterized by a steep gradient, and is sub-parallel to the inner border of the Alpine chain. In the following sections, the geological and kinematic meaning of the Iso-Kinematic domains and boundaries generated for the Iso-Kinematic Maps (IKM1 and IKM2) will be discussed.

\section{Discussion}

Iso-Kinematic Maps are compared with the geological, tectonic, geomorphologic, seismological data available for the study area. Even if not directly comparable in terms of absolute velocity, due to the different reference point and to the intrinsic properties own of each instrumental data, 
available GPS data (Devoti et al., 2011; see Fig. 6 and 7) were used to qualitatively constrain the differential uplift inferred by interferometric data as well.

Afterwards, the differential uplift obtained by interferometric data has been compared with that deduced from the analysis of the Late Pleistocene - Holocene deposits and from river drainage patterns (Fig. 8), to gain a better insight into the relationship between short- and long- period trends. Only the best-located seismic events, with a location error of less than $3 \mathrm{~km}$, were used, to have further constraints on the current tectonic activity.

\subsection{Differential uplift and crustal mobility in the IKM 1}

The IKM1 (Fig. 6) covers the westernmost sector of the Po Plain, between the Torino Hill and the Saluzzo area, and the major valley mouths draining the inner sector of the Western Alps (Susa, Sangone, Chisone and Pellice valleys). In the IKM1, the boundary between the inner border of the Cottian Alps and the Western Po Plain, characterized by different uplift, is steep and sub-parallel to the N-S faults dissecting the inner sector of the Alpine chain, such as the LTZ (Fig. 6a, d). In the southern part of the study area, between the Pellice and Chisone rivers, the Iso-Kinematic Boundary runs close to the trace of these faults while in the northern part, where the Stura di Lanzo and the Dora Riparia terraced megafans are present, this boundary is shifted to the east, and borders the Torino Hill to the west. The Iso-Kinematic Boundary strikes sub-parallel to the general trend of the seismicity and with the general attitude of the nodal planes of the focal solutions in this area, which usually correspond to N-S steep surfaces (Fig. 6c, d).

The distribution of strong positive and negative velocity values recorded in the Po Plain are in agreement with the differential uplift deduced, on a longer time-scale, by the different geomorphological evolution (Fig. 6c, d) observed in the area. South of the Torino Hill, the river Po is characterized by a well-developed meandering fluvial pattern, whilst north of the Torino Hill anticline, the fluvio-glacial succession is terraced, indicating a more uplifted sector, as also evidenced by GPS data (Ieng and Tori GPS stations in Fig. 6) that show the highest positive velocity values $(0.98 \pm 0.52 \mathrm{~mm} / \mathrm{yr}$ and $1.07 \pm 0.31 \mathrm{~mm} / \mathrm{yr}$ respectively $)$.

Within the Torino Hill domain, there are several small sectors characterized by low negative velocities alternating with wide sectors characterized by low-to-very low positive PS velocities, due to local distribution of gravitational phenomena and/or lithological constraints (Fig. 6). This kinematic tendency seems to be quite in agreement with the GPS information $(-0.46 \pm 1.1 \mathrm{~mm} / \mathrm{yr}$, Monc GPS station in Fig. 6). 
These PS-InSAR data are in contrast with the long-period differential uplift deduced by geological and geomorphological data (see par. 2.3), which indicate a protracted uplifting trend for the Torino Hill since the Late Pleistocene (Fig. 8).

In the south-eastern sector of the IKM1, a moderate PS concentration with positive velocity values is also observed, whose distribution falls in the hanging-wall of the Saluzzo-Sommariva del Bosco $\mathrm{N}$-verging thrust (SSB), which shows evidence of Mio-Pliocene tectonic activity (Mosca et al., 2009) and a more recent deformation phase in the Late Pleistocene, as inferred by the strong tilting of the left side of the Varaita megafan. The IKM also shows that the boundary with the adjoining areas is characterized by a gentle gradient and roughly corresponds to the trace of this subsurface structure. Short period differential uplift, obtained by PS data, is in agreement with that deduced, on a longer time scale, by the sharp variation of the drainage directions of the main rivers (Grana, Maira, Varaita and Po), from SW-NE to roughly N-S, located in correspondence of this structure (Fig. 8). The distribution of both shallow and intermediate seismic events near the SSB trace, showing reverse focal solutions with ENE-WSW reverse nodal planes, also suggests a relationship between the current activity of the SSB and the differential uplift in this area.

\section{Figure 6 here}

\subsection{Differential uplift and crustal mobility in the IKM2}

The IKM2 (Fig. 7) allows comparison of the present-day crustal mobility of the inner Cottian Alps, between the Sangone and Po valleys, and the Western Po Plain. In the IKM2, the Iso-Kinematic Boundary between the Alpine chain and the Western Po Plain nearly coincides with the regional N$\mathrm{S}$ faults affecting this area (Fig. 7d). The Iso-Kinematic Boundaries are also sub-parallel to the overall N-S trend of the instrumental seismicity, and in some cases join with the epicentres of the seismic events (Fig. 7a and 7d). In the northern part of the IKM2, this boundary is shifted to the east to border the Torino Hill western flank, as also observed in the IKM1.

Inside the Alpine chain, positive velocity values are observed along the Pellice and Chisone valley bottoms, where a thick sequence of strongly consolidated Early-Middle Pleistocene lacustine and fluvio-lacustrine deposits are present, indicating an overall positive velocity trend. Lessening of the positive velocity along the watersheds between the Sangone, Chisone and Pellice valleys show a good correlation with the distribution of the Deep Seated Gravitational Slope Deformations and landslides that are widespread along the valley slopes (Fig. 7c). This overall uplifting trend, 
obtained both by the analysis of the PS-InSAR and the GPS data (Devoti et al., 2011), is confirmed (Fig. 8) by the distribution of Late Pleistocene glacial deposits and by the Holocene fluvial terraces. In the westernmost Po Plain, mostly low-negative to negative values are observed, with a cluster of low positive velocities concentrated in the south-eastern part of the map (Saluzzo area) and along the Po River, confirming the general trend shown by the IKM1. GPS data (SAVI station in Fig. 7; $0.29 \pm 2.49 \mathrm{~mm} / \mathrm{yr}$ ), even if affected by large errors, seems to confirm this kinematic tendency. Similarly to the IKM1, the IKM2 displays an approximate correspondence between the low gradient Iso-Kinematic Boundary and the geometry of the SSB whereas, in the Torino Hill area, no relation between current differential uplift and Padanian Thrust Front is observed.

\section{Figure 7 here}

\section{Conclusions}

The integration of the different datasets suggests that the current tectonic activity and the differential uplift of the Cottian Alps/Po Plain boundary is mostly driven by the activity of a major $\mathrm{N}-\mathrm{S}$ fault (CABF in Fig. 8, 9), sub-parallel to the inner border of the Alpine chain. This interpretation is supported by the close agreement between the geometry and distribution of the IsoKinematic boundaries, characterized by very steep gradients, and N-S faults (LTZ and PGFS in Fig. 2, 6, 7, 8), already inferred as seismogenic faults (Perrone et al., 2010, 2011b).

PS-InSAR data suggest that the CABF is currently buried beneath the westernmost Po Plain. In the southern part of the study area it nearly coincides with the N-S faults observed along the Pellice and Chisone valley mouths, whilst it shifts to the east, in the northern part of the study area, to border the western side of the Torino Hill (Fig. 8b). This fault also seems to govern the current crustal mobility of the western Po Plain, causing differential uplifting between different sectors of the Western Po Plain (Fig. 8 and section 2.3).

The focal mechanisms observed along the Iso-kinematic Boundary bordering the Cottian Alps also suggest that the $\mathrm{CABF}$ is characterized by transpressive/reverse movements (Fig. 6, 7). By contrast, inside the Alpine chain, N-S faults are characterized by normal and subordinately dextral transtensive movements inside the chain, due to the coexistence of rotational and gravitational body forces (Perrone et al., 2010, 2011a, 2011b; Sue and Tricart, 2003).

\section{Figure 8 here}


In the South-Western Po Plain, PS data suggest that current tectonic activity can mainly be attributed to the Saluzzo-Sommariva del Bosco Thrust (SSB), as both the IKM (albeit with gentle gradients) and the distribution of PS velocity values, correspond to the geometry and kinematics of this fault (Fig. 7, 8). The uplift in the hanging-wall of this fault is also consistent with that deduced by geological, geomorphological and geophysical data (cfr. par. 2.2), which indicate an increase of activity for this structure since Pliocene times (Mosca et al., 2009). The shallow-to-intermediate seismicity, and the attitude of the nodal plane of focal mechanisms observed near the trace of this fault, also suggest current activity for this structure. Moreover, seismotectonic and interferometric data indicate that, in the adjoining area of the Tertiary Piemonte Basin, the seismicity is related to the activity of NE-SW transcurrent/transpressive faults (Massa et al., 2006).

By contrast, IKM do not show any relation between the current crustal mobility and the Padanian Thrust Front (PTF), as also indicated by the almost overall absence of evidence of Holocene activity, and by the lack of historical and instrumental seismicity along this structure. Fluvial terraces affecting the Torino Hill slopes and the Po diversion in the Pleistocene (Carraro et al., 1995) indicate, however, an overall uplifting trend on a longer time scale. This suggests that the decrease of the vertical movement component of Padanian Thrust Front is very recent (post-Late Pleistocene) and could be caused, as already indicated by Mosca et al. (2009), by the hindering of northward thrust propagation, due to the shallow depth of the south Alpine crust beneath the Torino Hill, and a consequent shift of the deformation in the south-westernmost Po Plain, where most of the seismic activity is currently observed.

The kinematic tendency in general seems to be in overall agreement with the GPS data even if these data cannot be directly compared, as already stressed above. Nevetherless, both the scarcity of GPS stations and the uncertainties that affect especially their vertical component of motion impose caution in the use of these data.

Moreover, the distribution and geometry of the Iso-Kinematic Boundaries seems to be only scarcely influenced by the compaction of the Plio-Quaternary alluvial deposits of the Po Plain or by hydrodynamic compaction phenomena induced by ground water exploitation as they are usually coarse grained and cemented. Non-tectonic subsidence could instead affect the low consolidated peat bog deposits observed south of Moncalieri (cfr. par. 3). The relatively restricted distribution of these deposits, in any case, does not seem to constitute a limitation to the analysis of the differential uplift in this area. 


\section{Figure 9 here}

In conclusion, this study indicates that, at the Western Po Plain termination, the ongoing indentation and related anticlockwise rotation, between the Adriatic and European plates, is accommodated by complex fault kinematics (Fig. 9). This has partitioned the different components of the bulk deformation at a regional scale, as already proposed by the recent tectonic interpretations (Sue and Tricart, 2003; Delacou et al., 2004, 2008; Perrone et al., 2010, 2011a, 2011b). The NW-SE oblique convergence between Adria and Europe, as also suggested by seismological data (Massa et al., 2006), seems to be accommodated by NE-SW thrust/transpressive faults in the Western Po Plain subsurface, and by N-S strike-slip faults along the inner border of the Cottian Alps. Both the magnitude of seismic events and the geodetic data, show that the indentation is currently characterised by low deformation rates (Calais et al., 2002; Sue et al., 2007).

\section{References}

Anderson, H.., Jackson, J., 1987. Active tectonics of the Adriatic region. Geophys. J.R. Astron. Soc. 91, 937-983.

Balestrieri, M.L., Bigazzi, G., Cadoppi, P., Sacchi, R., 2004. Studio preliminare di alcuni campioni di ortoderivati provenienti dalla val di Susa mediante il metodo delle tracce di fissione su apatite, in: Sacchi, R., Balestro, G., Cadoppi, P., Carraro, F., Delle Piane, L., Di Martino, L., Enrietti, M., Gallarà, F., Gattiglio, M., Martinotti, G., Perello, P. (Eds.), Studi geologici in Val di Susa finalizzati ad un nuovo collegamento ferroviario Torino-Lione. Museo Regionale Di Scienze Naturali, Torino, monograph series 41, pp. 103-115.

Bernet, M., Zattin, M., Garver, I., Brandon, M.T., Vance, J., 2001. Steady-state exhumation of the European Alps. Geology 29, 35-38.

Béthoux, N., Sue, C., Paul, A., Virieux, J., Fréchet, J., Thouvenot, F., Cattaneo M., 2007. Local tomography and focal mechanisms in the south-western Alps: comparison of methods and tectonic implications. Tectonophysics 432, 1- 19. 
Bello, M., Fantoni, R., 2002. Deep oil play in Po Valley: Deformation and hydrocarbon generation in a deformed foreland, in: Deformation History Fluid Flow Reconstruction and Reservoir Appraisal in Foreland Fold and Thrust Belt. American Association of Petroleum Geologists, Hedberg Conference, pp. 1-4.

Bigi, G., Castellarin, A., Coli, M., Dal Piaz, G.V., Sartori, R., Scandone, P., Vai, G.B., 1990. Structural Model of Italy, Sheet n.1. C.N.R., Progetto Finalizzato Geodinamica, Selca Firenze.

Boschi, E., Guidoboni, E., Ferrari, G., Mariotti, D., Valensise, G., Gasperini, P., 2000 - Catalogue of strong Italian earthquakes. Ann. Geofis. 43 (4), 268.

Cadoppi, P., Castelletto, M., Sacchi, R., Baggio, P., Carraro, F., Giraud, V., 2002. Note illustrative della Carta Geologica d'Italia, 1:50.000 scale, Susa - 154 Sheet. APAT, Rome - Italy.

Cadoppi, P., Giardino, M., Perrone, G., Tallone, S., 2007. Litho-structural control, morphotectonics and deep-seated gravitational deformations in the evolution of the alpine relief: a case study in the Lower Susa Valley (Italian Western Alps). Quat. International 171-172, 143-160.

Calais, E., Nocquet, J.M., Jouanne, F., Tardy, M., 2002. Current strain regime in the Western Alps from continuous Global Positioning System measurements, 1996-2001. Geology 30, 651-654.

Carminati, E., Martinelli, G., Severi, P., 2003. Influence of glacial cycles and tectonics on natural subsidence in the Po Plain (Northern Italy): insights from 14C ages. Geochem. Geophys. Geosyst. 4 (10), 1082.

Carraro, F., Collo, G., Forno, M.G., Giardino, M., Maraga, F., Perotto, A., Tropeano, D., 1995. L'evoluzione del reticolato idrografico del Piemonte centrale in relazione alla mobilità quaternaria. In: Polino, R., Sacchi, R., (Eds.), Rapporti Alpi-Appennino e guida alle escursioni. Accademia Nazionale delle Scienze, pp. 445-461.

Carraro, F., Baggio, P., Bellino, L., Cadoppi, P., Castelletto, M., Giraud, V., Mensio, L., 2002. Carta Geologica d'Italia,. 1:50.000 scale, Susa - 154 Sheet. APAT, Rome - Italy.

Cassano, E., Anelli, L., Fichera, R., Cappelli V., 1986. Pianura Padana: Interpretazione integrata di dati geofisici e geologici. $73^{\circ}$ Congr. Soc. Geol. It., 1-27. 
Champagnac, J.D., Molnar, P., Anderson, R.S., Sue, C., Delacou, B., 2007. Quaternary erosion induced isostatic rebound in the western Alps. Geology 35, 195-198. doi:10.1130/G23053A.1.

Clari, P., Dela Pierre, F., Novaretti A., Timpanelli, M., 1995. Late Oligocene - Miocene sedimentary evolution of the criticals Alps/Apennines junction: the Monferrato area, Northwestern Italy. Terra Nova 7, 144-152.

Colesanti, C., Ferretti, A., Novali, F., Prati, C., Rocca, F. 2003. SAR monitoring of progressive and seasonal ground deformation using the Permanent Scatterers Technique. IEEE Transactions on Geoscience and Remote Sensing 41(7), 1685-1701.

Collo, G., Giardino, M., 1997. Deformation of "Villafranchian" lacustrine sediments in the Chisone Valley (Western Alps, Italy). J. Geodynamics 24, 281-292.

Curlander, J.C., McDonough, R.N., 1991. Synthetic Aperture Radar: Systems and Signal Processing. John Wiley \& Sons, New York.

Delacou, B., Sue, C., Champagnac, J.D., Burkhard, M., 2004. Present-day geodynamics in the bend of the western and central Alps as constrained by earthquake analysis. Geophys. J. Int. 158, 753774.

Delacou, B., Sue, C., Nocquet, J.M., Champagnac, J.D., Allanic, C., Burkhard, M., 2008. Quantification of strain rate in the Western Alps using geodesy: comparisons with seismotectonics. Swiss J Geosci 101, 377-385.

Devoti R., Esposito A., Pietrantonio G., Pisani A. R., Riguzzi F., 2011. Evidence of large scale deformation patterns from GPS data in the Italian subduction boundary. Earth and Planetary Science Letters 311 (2011) 230-241

Eva, E., Solarino, S., Eva, C., Neri, G., 1997. Stress tensor orientation derived from fault plane solution in the Southwestern Alps. J. Geophys. Res. 102, 8171-8185. 
Eva, E., Solarino, S., 1998. Variation of stress directions in the western Alpine arc, Geophys. J. Int. $135,438-448$.

Ferretti, A., Prati, C., Rocca, F., 2000. Nonlinear subsidence rate estimation using Permanent Scatterers in differential SAR interferometry. IEEE Transactions on Geoscience and Remote Sensing 38(5), 2002-2012.

Ferretti, A., Prati. C., Rocca, F., 2001. Permanent Scatterers in SAR Interferometry. IEEE Transactions on Geoscience and Remote Sensing, 39 (1), 8-20.

Ferretti, A., Savio, G., Barzaghi, R., Borghi, A., Musazzi, S., Novali, F., Prati, C., Rocca, F., 2007. Submillimeter accuracy of InSAR time series: experimental validation. IEEE Transactions on Geoscience and Remote Sensing 45 (5), 1142-1153.

Festa, A., Boano, P., Irace, A., Lucchesi, S., Forno, M.G., Dela Piere, F., Fioraso, G., Piana, F., Polino, R., 2009. Torino Est - 156 sheet, Carta Geologica d'Italia, 1:50.000 scale. ISPRA, RomeItaly.

Fioraso, G., Bicchi, E., Irace, A., Boano, P., 2004. Manifestazioni carsiche nelle evaporiti messiniane del Monferrato e della Collina di Torino (Italia nord-occidentale): analisi dei meccanismi genetici nel quadro dell'evoluzione pliocenico-quaternaria del Bacino Terziario Piemontese. Il Quaternario 17, 453-476.

Gelati, R., Gnaccolini M., 1988. Sequenze deposizionali in un bacino episuturale, nella zona di raccordo tra Alpi e Appennino settentrionale. Atti Tic. Sc. Terra 31, 340-350.

Getis, A., Ord, J.K., 1992. The analysis of spatial association by use of distance statistics. Geographical Analysis 24(3), 189-206.

Hanssen, R., 2001. Radar interferometry: Data interpretation and error analysis. Kluwer Academic Publisher. 
Malusà, M., Polino, R., Zattin, M., Bigazzi, G., Martin, S., Piana, F., 2005. Miocene to present differential exhumation in the Western Alps: insights from fission track thermocronology. Tectonics 24, TC3004, Doi:10.1029/2004TC001782.

Massa, M., Eva, E., Spallarossa, D., Eva C., 2006. Detection of earthquake clusters on the basis of waveform similarity: An application in the monferrato region (Piedmont, Italy). Journal of Seismology 10, 1-22.

Morelli, M., Piana, F., Mallen, L., Nicolò, G., Fioraso, G., 2011. Iso-Kinematic Maps from statistical analysis of PS-InSAR data of Piemonte, NW Italy: Comparison with geological kinematic trends. Remote Sensing of Environment, 115, 1188-1201.

Mosca, P., 2006. Neogene basin evolution in the Western Po Plain (NW Italy). PhD Thesis, CNR IGG- University of Amsterdam, 190 pp.

Mosca, P., Polino, R., Rogledi, S., Rossi M., 2009: New data for the kinematic interpretation of the Alps-Apennines junction (Northwestern Italy). Int. J. Earth. 99, 833-849.

Nocquet, J.M., Calais, E., 2003. Crustal velocity field of Western Europe from permanent GPS array solutions, 1996-2001. Geoph. J. Int. 154, 72-88.

Ord, J.K., Getis, A., 1995. Local spatial autocorrelation statistics. Geographical Analysis, 4(27), 286-306.

Perrone, G., Eva, E., Solarino, S., Cadoppi, P., Balestro, G., Fioraso, G., Tallone, S., 2010. Seismotectonic investigations in the inner Cottian Alps: an integrated approach. Tectonophysics 496, 1-16.

Perrone, G., Cadoppi, P., Balestro, G., Tallone, S., 2011a. Post-collisional tectonics in the Northern Cottian Alps (italian Western Alps). Int. J. Earth Sciences 100, 1349-1373.

Perrone, G., Eva, E., Cadoppi, P., Solarino, S., Fioraso, G., 2011b. Seismotectonics of a lowdeformation area: the Central Western Alps (Italy). Bollettino di Geofisica Teorica ed Applicata 522, 261-281. 
Piana, F., Polino, R., 1995. Tertiary structural relationships between Alps and Apennines: the critical Torino Hill and Monferrato area, Northwestern Italy. Terra Nova 7, 138-143.

Piana, F., 2000. Structural features of western Monferrato (Alps-Apennines junction zone, NW Italy). Tectonics 19, 943-960.

Polino, R., Dal Piaz, G.V., Gosso, G., 1990. Tectonic erosion at the Adria margin and accretionary processes for the Cretaceous orogeny of the Alps. Mem. Soc. Geol. France 156, 345-367.

Polino, R., Dela Pierre, F., Fioraso, G., Giardino, M., Gattiglio, M., 2002. Bardonecchia 132,152,153 sheet, Carta Geologica d'Italia, 1:50.000 scale. APAT, Rome-Italy.

Rossi, M., Mosca, P., Polino, R., Rogledi, S., Biffi, U, 2009. New outcrop and subsurface data in the Tertiary Piedmont Basin (NW- Italy): unconformity-bounded stratigraphic units and their relationships with basin-modification phases. Riv. Ital. Paleont. Strat. 3, 305-335.

Sue, C., Thouvenot, F., Frechét, J., Tricart, P., 1999. Widespread extension in the core of the western Alps revealed by earthquake analysis. J. Geoph. Res. 104, 25611-25622.

Sue, C., Tricart, P., 2003. Neogene to current normal faulting in the inner western Alps: A major evolution of the late alpine tectonics. Tectonics 22(5):1050, doi:10.1029/2002TC001426, 2003.

Sue, C., Delacou, B., Champagnac, J.D., Allanic, C., Tricart, P., Burkhard, M., 2007. Extensional neotectonics around the bend of the Western/Central Alps: an overview. Int. J. Earth Sci. 96, 11011129.

Tallone, S., Cadoppi, P., Balestro, G., Delle Piane, L., Perello, P., Riccio, I., 2002. Ductile-to-brittle tectonic evolution at the structural knot between the Lower and Middle Susa Valley (Province of Turin). Abstracts of the $81^{\text {th }}$ Congress of the Italian Geological Society, Turin 10-12 September 2002, 310-311.

Tricart, P., Van der Beek, P., Schwartz, S., Labrin, E., 2007. Diachronous late-stage exhumation across the western Alpine arc: constraints from apatite fission-track termochronology between Pelvoux and Dora-Maira Massifs. Geological Society, London 164, 163-174. 
Tropeano, D., Cerchio, E., 1984. L'orizzonte torboso wurmiano nel sottosuolo della pianura piemontese meridionale. Osservazioni preliminari. Boll. Ass. Min. Sub. 21(3), 199-221.

Vigna, B., Fioraso, G., Banzato, C., De Waele, J., 2010. Evolution of karst in Messinian gypsum (Monferrato, Northern Italy). Geodinamica Acta 23(1-3), 29-40.

Ward, S., 1994. Constraints on the seismotectonics of the central Mediterranean from very long baseline interferometry. Geophys. J. Int. 117, 441-452. 


\section{Figure captions}

Figure 1: tectonic sketch of the Western Alps. The dashed rectangle shows the study area. AB: Alessandria Basin; GB: Gonfolite Basin; M: Monferrato; SB: Savigliano Basin; TH: Torino Hill;

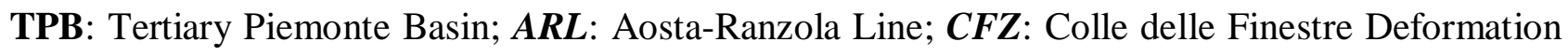
Zone; $\boldsymbol{C H L}$ : Chamonix Line; CL: Canavese Line; $\boldsymbol{C R L}$ : Cremosina Line; $\boldsymbol{L F}$ : Longitudinal fault system; LTZ: Col del Lis-Trana Deformation Zone; OSL: Ospizio-Sottile Line; OSZ: Orco Shear Zone; PF: Penninic Front; PTF: Padanian Thrust Front; RFDZ: Rio Freddo Deformation Zone; $\boldsymbol{R L}$ : Rodano Line; $\boldsymbol{S A F}$ : Southern Alpine Thrust; SF: Simplon Fault; SSB: Saluzzo-Sommariva del Bosco Thrust; STF: Stura Fault; $\boldsymbol{S V L}$ : Sestri-Voltaggio Line; $\boldsymbol{T F}$ : Transverse Faults; $\boldsymbol{T L}$ : Tonale Line; $\boldsymbol{V} \boldsymbol{V L}$ : Villavernia-Varzi Line. After Bigi et al. (1990).

Figure 2: tectonic sketch of the study area (from Perrone et al., 2010). CF: Chisone Fault, $\boldsymbol{C F Z \text { : }}$ Colle delle Finestre Deformation Zone, LTZ: Lis-Trana Deformation Zone, PGFS: Pinasca-Gran Dubbione fault system, PTF: Padanian Thrust Front, SFS: Sangone Fault system, SSB: SaluzzoSommariva del Bosco Thrust. DSGSD: Deep Seated Slope Gravitational Deformation.

Figure 3: geological cross-sections showing the geometry and kinematics of the regional fault systems in the inner Western Alps and Western Po Plain. The traces of the sections are shown in Figure 1. CFZ: Colle delle Finestre Deformation Zone, IF: Insubric Fault; LTZ: Col del Lis-Trana Deformation Zone, PTF: Padanian Trust Front; RFDZ: Rio-Freddo Deformation Zone; SAF : South Alpine thrust; SSB: Saluzzo-Sommariva del Bosco Thrust. Section 1-1' after Perrone et al., 2010; sections 2-2' and 3-3' after Mosca (2006).

Figure 4: seismotectonic map (seismicity with location error less than $3 \mathrm{~km}$ ) of the study area with related cross-sections. The compressional and extensional quadrants of the focal mechanisms are represented in white and grey, respectively. Instrumental seismicity from the database of the RSNI, historical seismicity from Boschi et al. (2000). Modified from Perrone et al. (2010). Abbreviations as in Fig. 2. 
Figure 5: PS distribution in sectors 1 (a) and 2 (b) with related velocity values. The histogram frequency diagrams show the statistical distribution of velocity values for sectors 1 (c) and 2 (d). The black squares in (a) and (b) indicate the fixed reference points.

Figure 6: (a) structural sketch of sector 1 with instrumental seismicity and focal mechanisms; (b) distribution of the gravitational phenomena in sector 1; (c) Hot Spot results calculated with $\mathrm{d}=2.5$ $\mathrm{km}$, red and blue points represent high and low $\mathrm{Z}\left(\mathrm{Gi}^{*}\right)$ values, respectively, in relation to the expected values obtained from equation 2 (see text); (d) Iso-Kinematic Map (IKM 1), expressed in high and low values of $\mathrm{Z}\left(\mathrm{Gi}^{*}\right)$, in red and blue areas, respectively. Rectangles filled with gray solid lines show the Iso-Kinematic Boundaries. Seismicity from RSNI network. Focal mechanisms from Perrone et al. (2010 and references therein). GPS data from Devoti et al. (2011). LTZ: Col del LisTrana Deformation Zone; PTF: Padanian Trust Front; PZ: Piemonte Zone; RFDZ: Rio-Freddo Deformation Zone; SSB: Saluzzo-Sommariva del Bosco Thrust. DSGSD: Deep Seated Slope Gravitational Deformation.

Figure 7: (a) structural sketch of sector 2 with instrumental seismicity and focal mechanisms; (b) distribution of the gravitational phenomena in sector 2; (c) Hot Spot results calculated with d=2.5 $\mathrm{km}$ : red and blue points represent high and low $\mathrm{Z}\left(\mathrm{Gi}^{*}\right)$ values, respectively, in relation to the expected values obtained from equation 2 (see text); (d) Iso-Kinematic Map (IKM 2), expressed in high and low values of $\mathrm{Z}\left(\mathrm{Gi}^{*}\right)$, in red and blue areas, respectively. Rectangles filled with gray solid lines show the Iso-Kinematic Boundaries. Seismicity from RSNI network. Focal mechanisms from Perrone et al. (2010 and references therein). GPS data from Devoti et al. (2011). CF: Chisone Fault; LTZ: Col del Lis-Trana Deformation Zone; PGFS: Pinasca-Gran Dubbione Fault System; SFS: Sangone Fault System; SSB: Saluzzo-Sommariva del Bosco Thrust. DSGSD: Deep Seated Slope Gravitational Deformation.

Figure 8: (a) differential uplift obtained by the analysis of Late Pleistocene- Holocene deposits. + and - indicate sectors characterized by relative uplift or subsidence respectively, $\div$ indicate sectors characterized by relative stability; thick red dashed lines indicate sharp boundaries between sectors characterized by different uplift; (b) interpretative structural map, with related cross-sections, showing the relationship between faults and current differential uplift at the Cottian Alps/Po Plain boundary. The fault network is shown in black; The fault $(\boldsymbol{C A B F})$ represented in red is interpreted on the basis of PS data. + and - indicate sectors characterized by positive and negative PS velocity 
values, respectively. $\boldsymbol{C A B F}$ : Cottian Alps Border Fault; $\boldsymbol{L T Z}$ : Col del Lis-Trana Deformation Zone; SSB: Saluzzo-Sommariva del Bosco Thrust.

Figure 9: (a) map of the current stress and strain regime in the Western Alps and Western Po Plain obtained by seismological and geodetic data (after Sue and Tricart, 2003; Delacou et al., 2004); (b) tectonic sketch of the Cottian Alps and the adjoining Po Plain with the possible active faults. Abbreviations as in Fig. 8.

Table 1: descriptive statistics of PS data in the IKM1 and IKM2. 
Fig.1
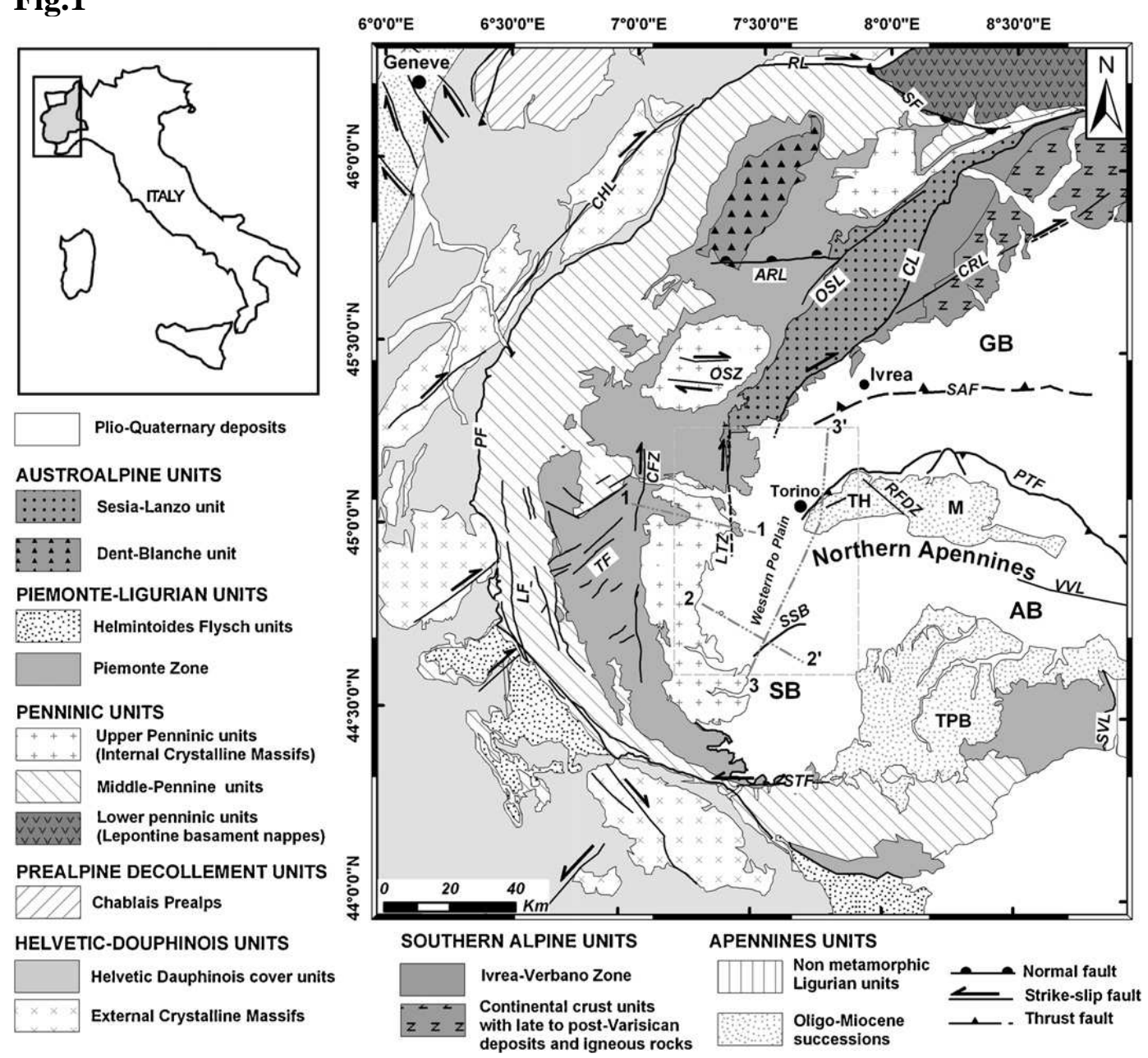

Fig. 2

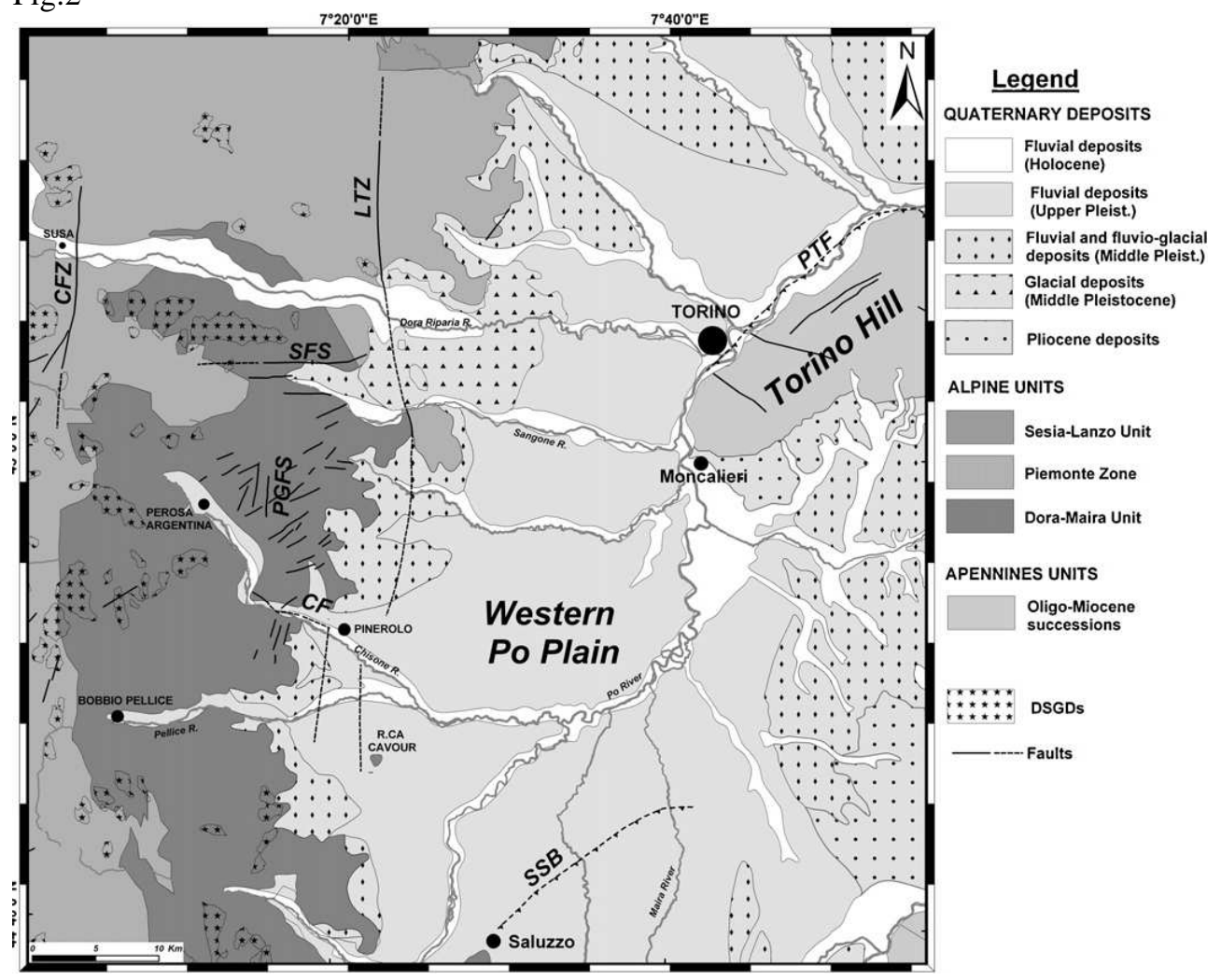


Fig. 3
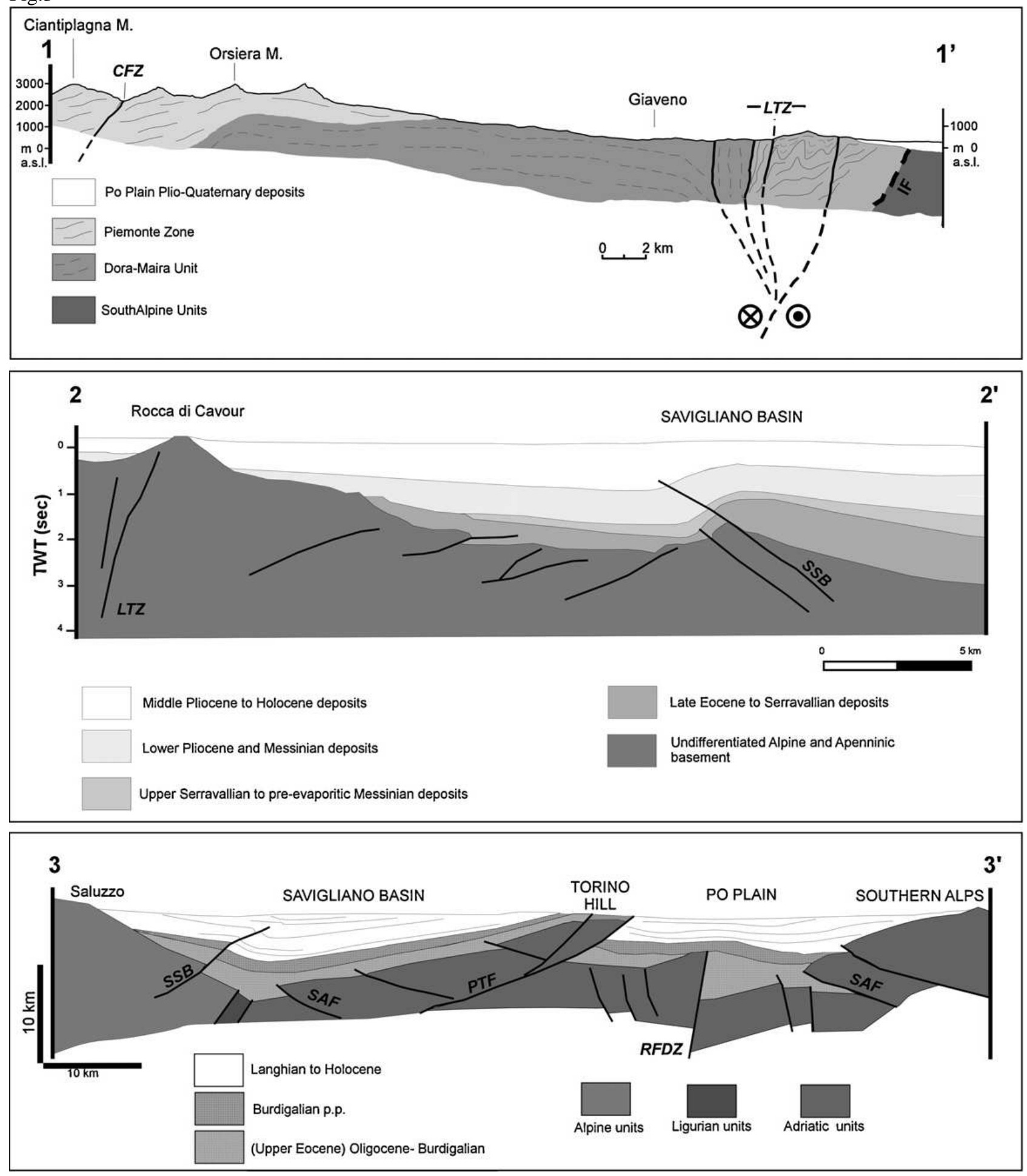
Fig. 4

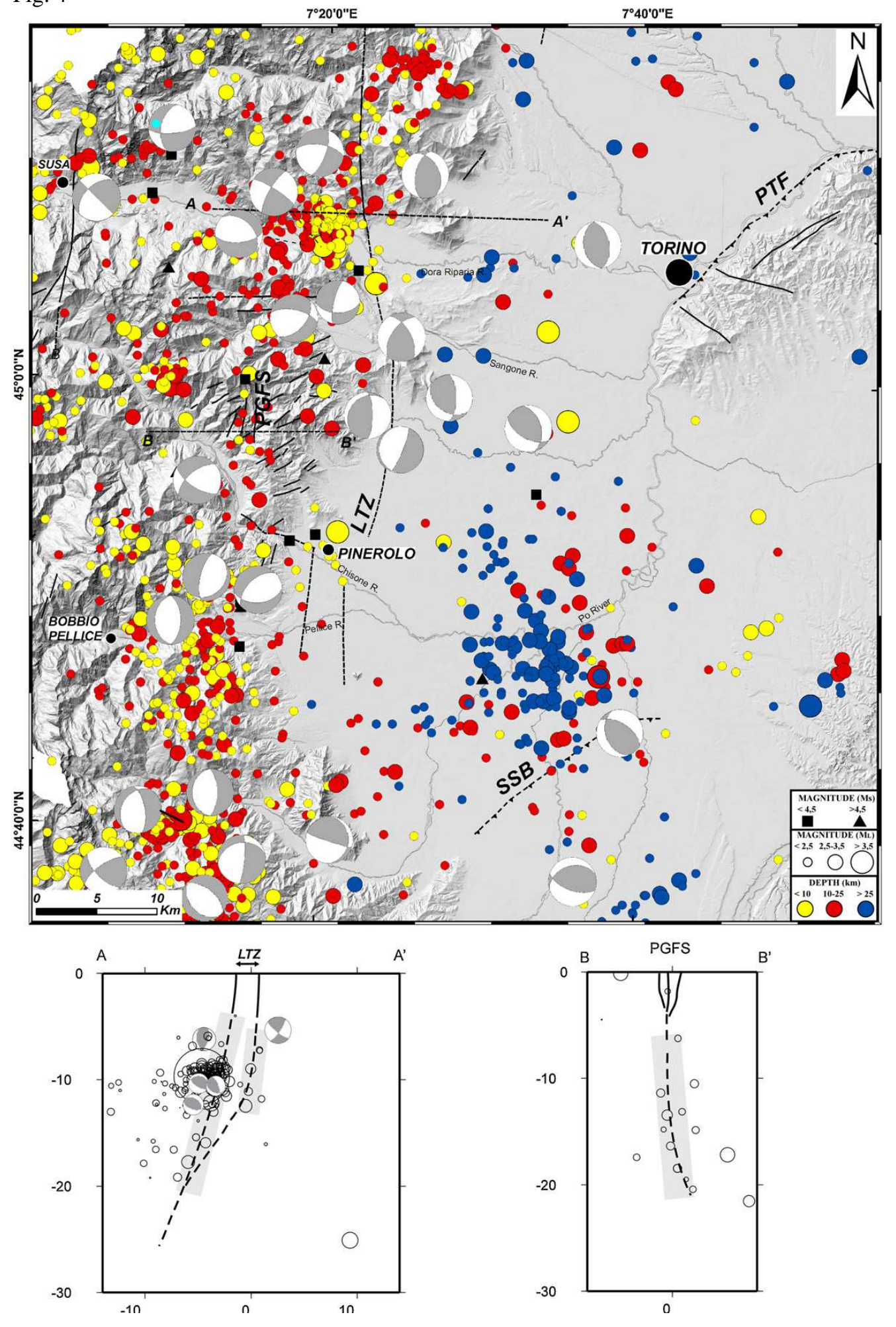


Fig.

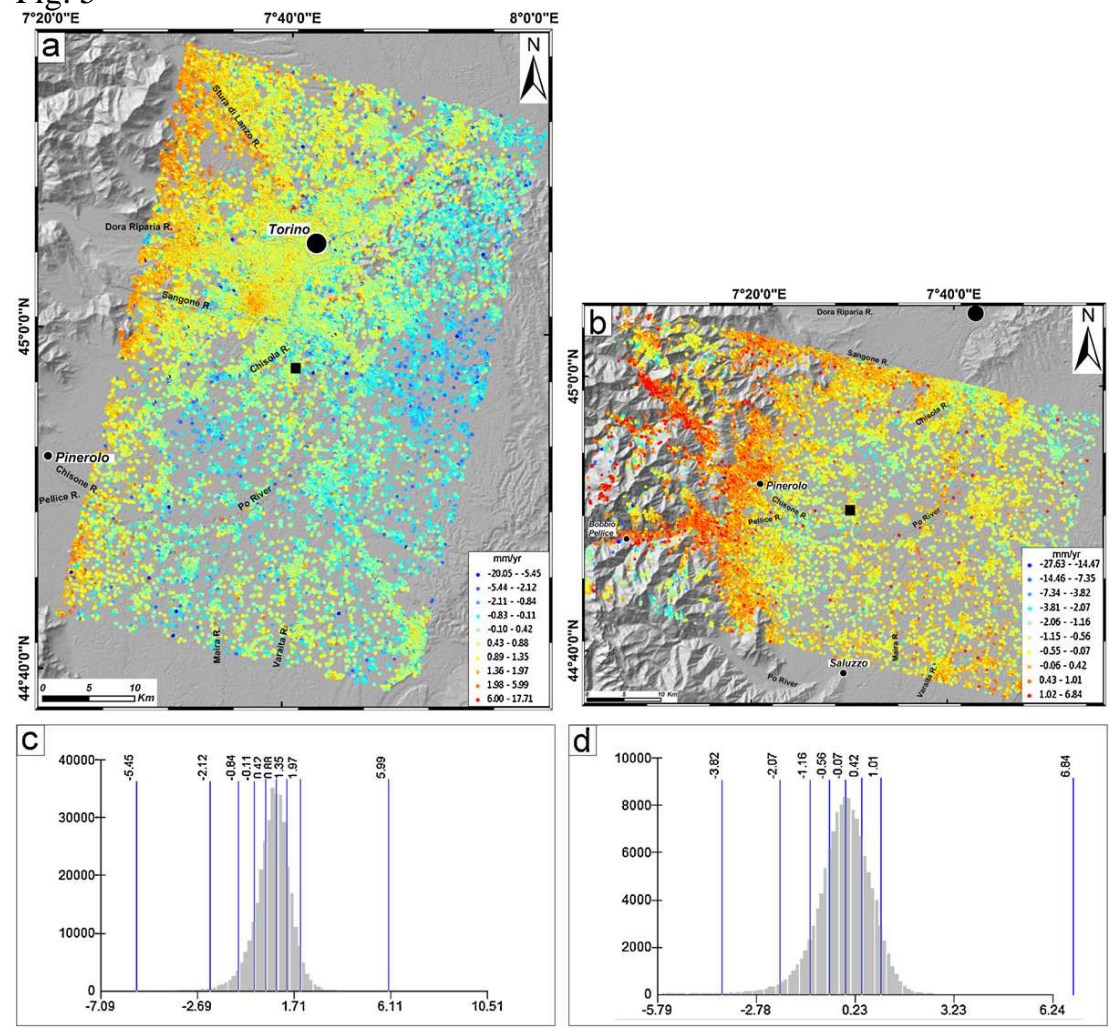

Fig. 6

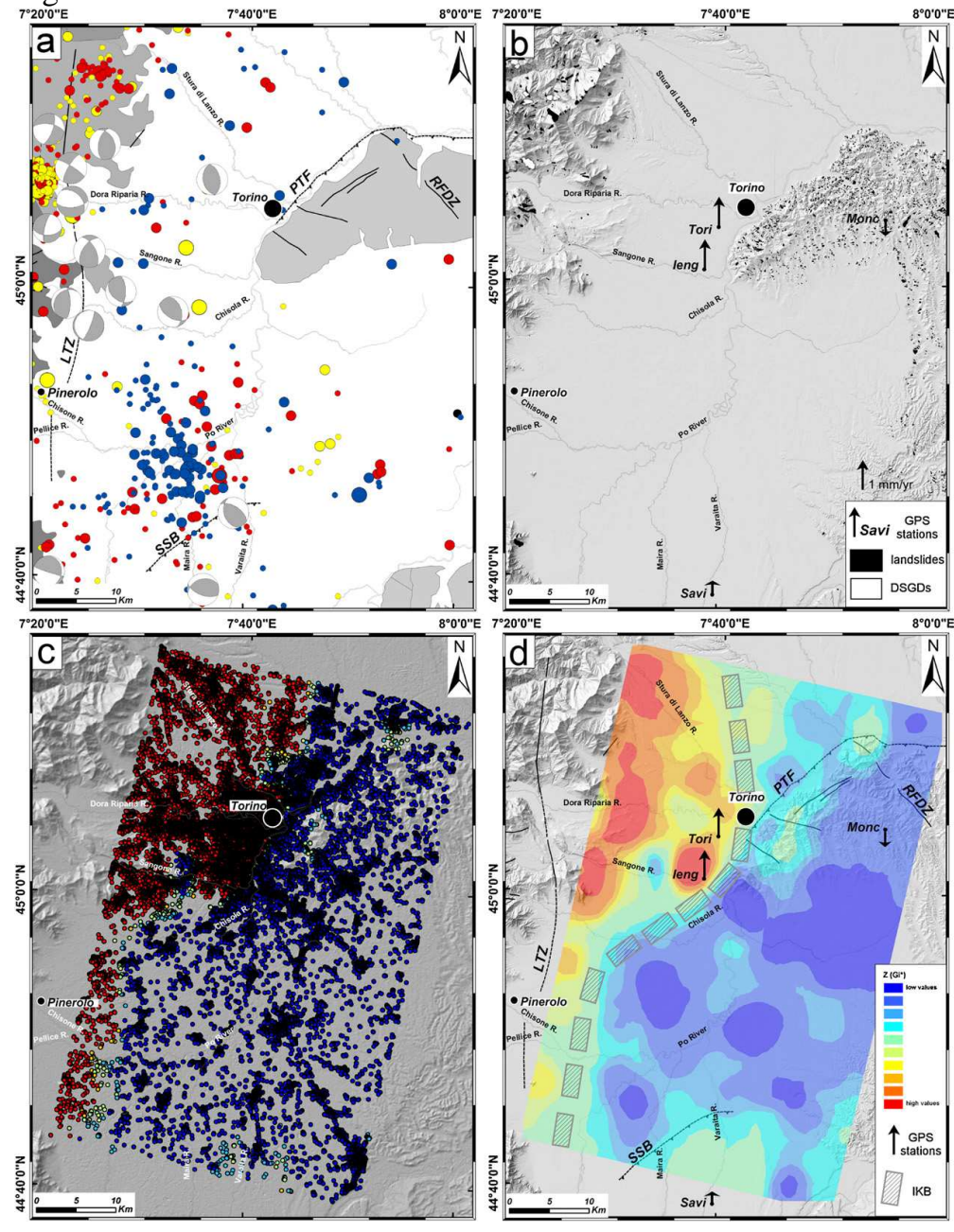


Fig. 7

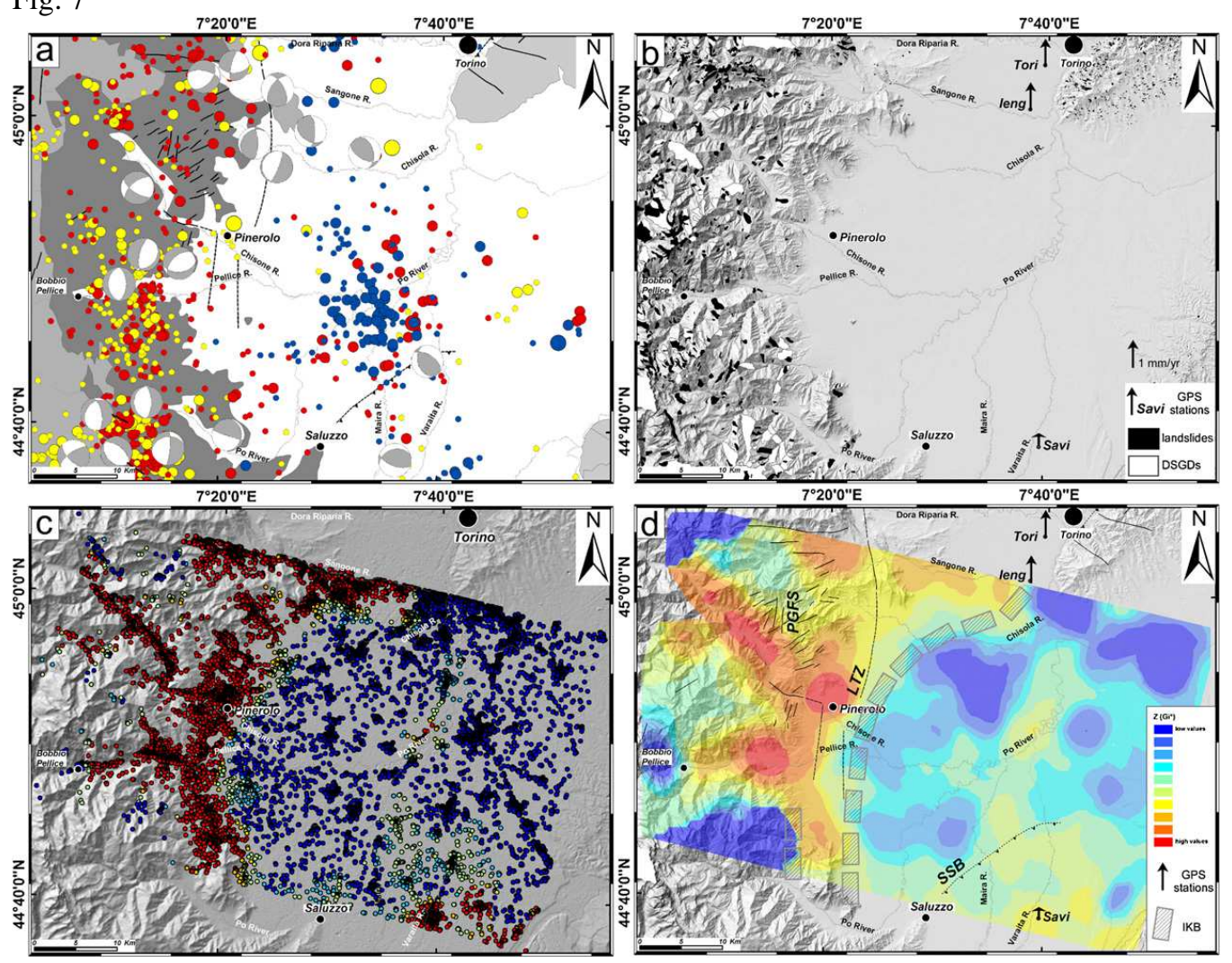

Fig. 8

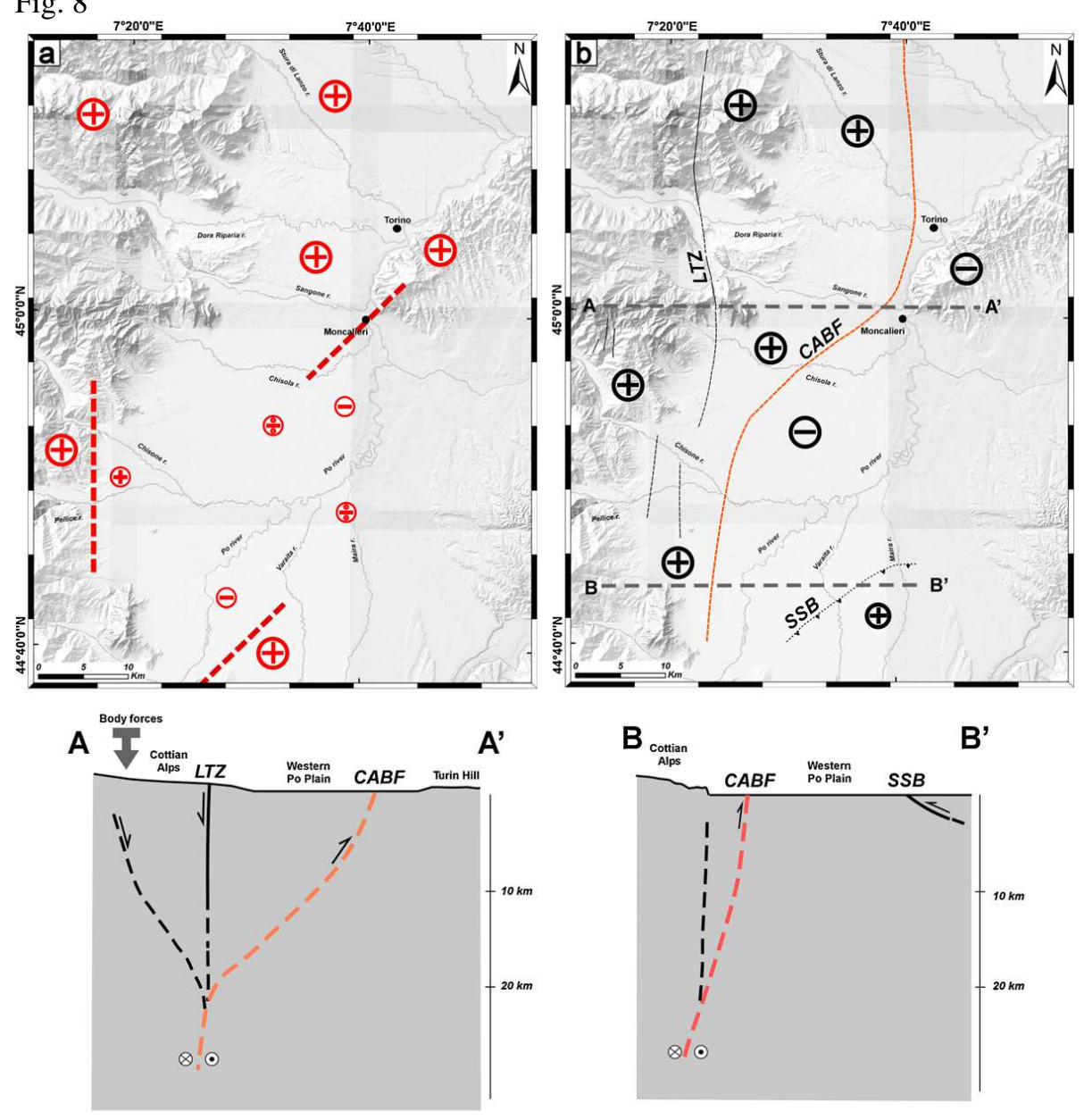


Fig. 9

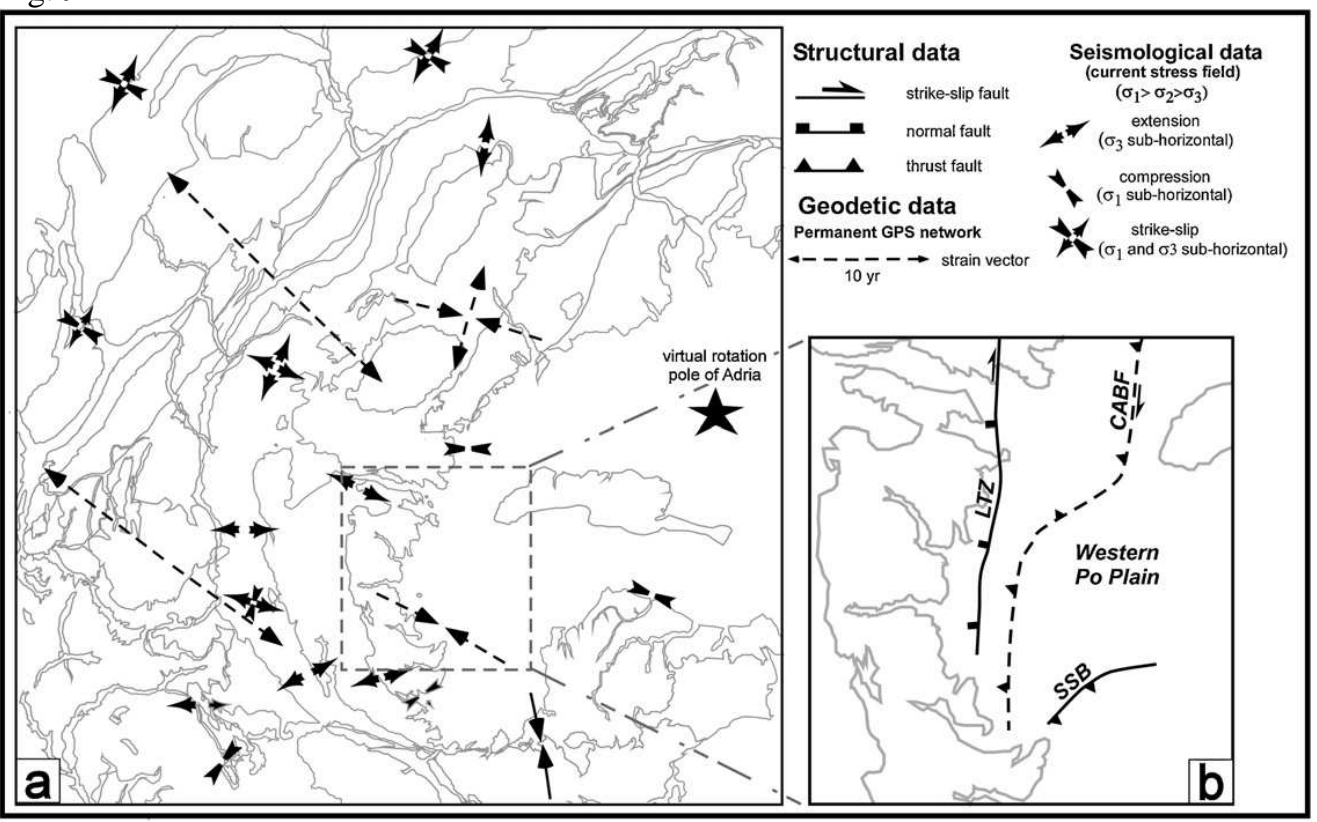

Table 1

Descriptive statistics of PS data in the IKMI and IKMZ

\begin{tabular}{|c|c|c|c|c|c|c|c|c|c|c|}
\hline & Num_PS & Min & Max. & Mean & Std, Dev. & Skewnes: & Kartasis & Ist quantile & Median & Ind quantile \\
\hline [KMI & 739718 & -20.05 & 01.7576389 & 21.52361 & 0.59167 & -1.164 & 1735 & 0.72 & 144 & 1.27 \\
\hline IXN2 & 1264344 & -27.67 & 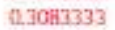 & -2.129 & 7. 68264 & -3.37 & 43.56 & -0.57 & -126 & 0.44 \\
\hline
\end{tabular}

